Уманська В. Г., к.е.н., доцент

Радзіховська Ю. М., к.е.н., доцент

Черкаський національний університет

імені Богдана Хмельницького

м. Черкаси, Украӥна

DOI: https://doi.org/10.30525/978-9934-26-068-1-36

\title{
НЕСТАНДАРТНІ ФОРМИ НАДАННЯ БІЗНЕС-ОСВІТНІХ ПОСЛУГ
}

Ринок бізнес-освіти останнім часом зазнає драматичні зміни. Він стає більш зрілим. Раніше переважали і були затребувані бізнес-школи, які давали набір менеджерських компетенцій (MBA): вміння вести переговори, лідерство і організаційна поведінка, управління операціями, ризиками, маркетинг i фінанси, цінова аналітика і т.д.

Навчання бізнес-навичкам залишається одним 3 найбільш недооцінених секторів в сфері освіти, але при цьому має колосальний потенціал зростання. Особливо в умовах економічної невизначеності, коли старі бізнес-моделі раптом стали неефективними, а новим навчатися ніде.

Пандемія негативно впливає на ринок бізнес-освіти, оскільки настрій споживача цього продукту - не пробувати нові формати, а поставити на паузу цей вид навчання до моменту, коли ситуація буде більш стабільною. Правила зараз непрозорі, і це багатьох зупиняє. При цьому для самих освітніх інституцій онлайн надає доступ до нових аудиторій [2].

Сьогодні стали затребувані наступні бізнес-компетенції: як зберегти бізнес в будь-яких обставинах; як знати межі власних можливостей, щоб не ризикувати нерозумно; як знайти i привласнити екстраординарні можливості; як розширити функціональну зону.

Існує багато способів розвивати компетенції співробітників. Варто розглядати не просто навчання, а й особистісний розвиток. MBA-програма довгий час була домінуючим форматом в бізнес- 
освіті. Однак за останні десять років вже з'явилося і використовується безліч інших інструментів. По-перше, змінюється сам підхід до навчання. Багато організацій створюють власні бази електронного навчання. Співробітників орієнтують на корпоративний розвиток на підставі електронного навчання, і ця тенденція посилюється. Роботодавцям не настільки важливо, є у їх співробітників диплом МВА чи ні, оскільки їм необхідно, щоб співробітник мав певні навички і вмів приймати правильні рішення. Якщо електронна система дозволяє отримати все це, то ій буде віддаватися перевага [1].

По-друге, сучасні молоді люди більше орієнтовані на електронний формат навчання. Дуже часто, коли в компанії їх просять вирішити певну проблему, вони не питають, на якому тренінгу їм отримати необхідні навички. Вони запитують, де це $\epsilon$ в Інтернеті, в якій системі e-learning вони можуть набути необхідних навичок. Навчання в Інтернеті за допомогою корпоративних дистанційних систем - це вже істотна загроза МВА-програми. Ці системи весь час розвиваються, стають все більш цікавими i захоплюючими. Спектр такого формату навчання багато в чому здатний конкурувати з програмою МВА. А за рівнем залучення співробітників і здатності їх зацікавити деякі електронні програми не просто є гідними конкурентами, а й перевершують академічних викладачів курсів МВА.

На думку багатьох аналітиків епоху класичних програм MBA очікує серйозна трансформація. Сам формат цих програм, які пропонуються у всіх бізнес-школах світу, перестає відповідати реальним потребам студентів. Саме тому ряд програм МВА в майбутньому може бути закритий. На зміну програмами МВА прийдуть більш сучасні і актуальні спеціалізовані програми магістратури, Сертифікатні та дипломні курси, а також короткострокові курси різних спеціалізацій.

Академічні програми нових форматів також будуть підкріплюватися спеціальними підприємницькими та некомерційними проектами, які навчатимуть студентів застосуванню отриманих знань на практиці. Наприклад, в програми Бізнес-школи 
ім. Стівена Росса в складі Мічиганського університету впроваджена 7-тижнева мультидисциплінарна консалтингова програма Action Project, в Гарвардській бізнес-школі також є своя практична програма лідерського розвитку - Field Immersion Experiences for Leadership Development.

Разом 3 форматом програм може змінитися і їх спрямованість. Це необхідно сучасним студентам, які хочуть стати посправжньому конкурентоспроможними фахівцями. В майбутньому бізнес-програми стануть більш індивідуалізованими i гнучкими. 3'являться нові більш вузькі спеціалізації, і збільшиться кількість курсів 3 подвійними спеціалізаціями. Оскільки знань i навичок, які студент може отримати на загальній класичній бізнес-програмі, часто вже недостатньо для успішної роботи, виникає потреба в додаткових уміннях і компетенціях. Майбутнє - за програмами, що об’єднують кілька спеціалізацій, наприклад, в бізнесі і інженерії, бізнесі та медицині, бізнесі та туризмі, і т.д. [2]

Найважливішою складовою бізнес-програм $\epsilon$ проходження стажувань. Для багатьох студентів саме проходження стажувань виявляється найкоротшим шляхом до подальшого успішного працевлаштування. Крім того, за рахунок стажування студент ще під час навчання може отримати досвід роботи, який потрібен для використання багатьох роботодавців.

Сформований тренд - гейміфікація навчання i в цілому процесів кар'єрного розвитку в компаніях. Це можна представити у вигляді створення ігрових майданчиків, на яких можна вчитися і розвивати свої здібності. Оскільки людям властиво приймати участь в іграх, це призводить до більшого залучення i захопленню, що в результаті дає більш високий рівень засвоєння знань. Гейміфікація має бути присутня і в МBA, інакше ці програми перестануть бути конкурентоспроможними.

Освітній симулятор, в якому в ігровій, легкій формі крок за кроком надається можливість вивчати фінанси. $Є$ можливість освоїти навички, як у справжньому бізнесі, тільки не ризикуючи реальними грошима. 
Наприклад, фінансовий директор з вигаданої компанії з обігом 1 мільйон доларів влаштовується фінансистом в технологічну компанію, яка планує зробити революцію на ринку альтернативних джерел енергії та заробити багато грошей. У симуляторі поступово зіткнетеся 3 ключовими проблемами малого та середнього бізнесу і навчиться їх вирішувати.

Такий формат навчання буде корисним: бухгалтерам (розбереться в управлінському обліку, плануванні, фінансових моделях, щоб стати фінансистом і отримати підвищення), фінансистам (отримає перший досвід в роботі фінансиста i розширить експертизу, щоб впевнено працювати з актуальними інструментами і в майбутньому зайняти посаду фінансового директора), топ-менеджерам (отримає експертизу в фінансах і управлінському обліку, щоб розраховувати бюджети проектів та ефективно приймати рішення.

Конкурують 3 традиційним бізнес-освітою також різні формати придбання навичок, але не знань. Наприклад, грамотно організований в компанії коучинг або командна робота 3 новими співробітниками, може стати такою альтернативою [1].

Бізнес форум - одне з особливо масштабних бізнес-заходів. Цей формат стає особливо популярним, тому що охоплює велику аудиторію, дозволяє спілкуватися напівформально, досить вільно для офіційних заходів і включає всі види (або більшу їх частину) бізнес-подій. На форумах можна голосно заявити про себе навіть тим, хто тільки починає діяльність, встановити важливі контакти. Але масштаб заходу i його структура надзвичайно складні в організації, тому вимагають багато часу для підготовки, а також високого професіоналізму організаторів [2].

Підготовка ділових заходів-форумів вимагає пошуку майданчика, учасників, розробки рекламної компанії та інформаційної підтримки, бронювання житла для гостей і організації трансферу 3 аеропортів, з вокзалів, харчування гостей, оформлення приміщень, складання культурно-розважальної програми і рішення ще безлічі питань. Ці завдання типові для організації бізнес-заходів, 
але їх рішення ускладнюється великим охопленням учасників, величезною кількістю подій в рамках форуму.

Форуми є унікальними для бізнес освіти, оскільки надають можливості для здобуття практичних навичок під час вивчення реально функціонуючих бізнес стратегій, а здобуті контакти сприяють входженню в бізнес середовище задовго до закінчення навчання.

Отже, на сьогодні бізнес освіта перебуває на етапі кардинальних перетворень, як формату проведення, та i змістовного наповнення. На перший план виходить важливість переведення навчання в онлайн формат без втрати якості та максимальна практичність обраних форматів.

\section{Література:}

1. Ринок освітніх послуг: виклики сучасності: Збірник матеріалів науковопрактичної конференції з міжнародною участю (м. Київ, 11 червня 2019 р.). Київ: АПСВТ, 2019. 98 с

2. Сучасні тенденції розвитку інформаційно-комунікаційних технологій в освіті: зб. Матеріалів II Міжнародної науково-практичної конференції в рамках Міжнародного освітнього форуму «Цифрова трансформація освіти». Рівне: РОІППО, 2020. $78 \mathrm{c}$.

3. Шевченко Л.С. Стратегічний консалтинг: теорія, практика, бізнесіндустрія. Економічна теорія та право. Харків, 2019. № 2 (37). С. 48-66. 